Check for updates

Cite this: RSC Adv., 2019, 9, 810

Received 29th October 2018

Accepted 18th December 2018

DOI: $10.1039 / \mathrm{c} 8 \mathrm{ra0} 8962 \mathrm{k}$

rsc.li/rsc-advances

\section{Nano-sized mesoporous phosphated tin oxide as an efficient solid acid catalyst $\uparrow$}

\author{
S. M. Hassan, ${ }^{a}$ M. A. Mannaa (D) ab and Amr Awad Ibrahim (D) *ac
}

Herein, we prepared a mesoporous tin oxide catalyst $\left(\mathrm{mSnO}_{2}\right)$ activated with phosphate species by the adsorption of phosphate ions from a phosphoric acid solution onto tin oxyhydroxide $\left(\mathrm{Sn}(\mathrm{OH})_{4}\right)$ surface. The phosphate content ranged from 3 to $45 \mathrm{wt} \%$. The nonaqueous titration of $n$-butylamine in acetonitrile was used to determine the total surface acidity level. FTIR of chemically adsorbed pyridine was used to differentiate between the Lewis and Brönsted acid sites. Thermal and X-ray diffraction analysis indicated that the addition of phosphate groups stabilized the mesostructure of $\mathrm{mSnO}_{2}$ and enabled it to keep its crystalline size at the nanoscale. FTIR analysis indicated the polymerization of the $\mathrm{HPO}_{4}{ }^{2-}$ groups into $\mathrm{P}_{2} \mathrm{O}_{7}{ }^{4-}$, which in turn reacts with $\mathrm{SnO}_{2}$ to form a $\mathrm{SnP}_{2} \mathrm{O}_{7}$ layer, which stabilizes the mesoporous structure of $\mathrm{SnO}_{2}$. The acidity measurements showed that the phosphate species are distributed homogeneously over the $\mathrm{mSnO}_{2}$ surface until surface saturation coverage at $25 \mathrm{wt} \% \mathrm{PO}_{4}{ }^{3-}$, at which point the acid strength and surface acidity level are maximized. The catalytic activity was tested for the synthesis of hydroquinone diacetate, where it was found that the \% yield of hydroquinone diacetate compound increased gradually with the increase in $\mathrm{PO}_{4}{ }^{3-}$ loading on $\mathrm{mSnO}_{2}$ until it reached a maximum value of $93.2 \%$ for the $25 \% \mathrm{PO}_{4}{ }^{3-} / \mathrm{mSnO}_{2}$ catalyst with $100 \%$ selectivity and excellent reusability for three consecutive runs with no loss in activity.

\section{Introduction}

The replacement of liquid acid or acid halide catalysts, such as $\mathrm{H}_{2} \mathrm{SO}_{4}, \mathrm{H}_{3} \mathrm{PO}_{4}$, HF and $\mathrm{AlCl}_{3}$, is a critical factor for the design of cleaner processes for green catalytic action. ${ }^{1}$ The problems of homogeneous liquid acid catalysis include toxicity, corrosion, catalyst waste and difficulty in separation and recovery. ${ }^{2}$ The economics of the separation cost majorly determine the viability of such a process. ${ }^{3}$ Efforts have been made to design environmentally safe processes and technologies to achieve these goals. The best catalytic technology for solving the problems of the liquid acid catalyst is to replace it by a heterogeneous solid acid catalyst. ${ }^{4}$ The reuse and recycling of the catalyst in heterogeneous processes are the main advantages of the increased catalyst efficiency over homogeneous ones. ${ }^{5}$ The presence of an interconnected network of a large number of pores, acid sites of different strength and the hydrophobic properties of solid catalyst surfaces support inhibiting the processes of corrosion and separation and for limiting pollution

${ }^{a}$ Chemistry Department, Faculty of Science, Mansoura University, Mansoura, Egypt. E-mail: amr_awad@mans.edu.eg

${ }^{b}$ Chemistry Department, Faculty of Education and Science, Amran University, Sa'dah, Yemen

${ }^{c}$ Department of Chemistry, Virginia Commonwealth University, Richmond, VA 232842006, USA

$\dagger$ Electronic supplementary information (ESI) available. See DOI: 10.1039/c8ra08962k problems. ${ }^{2}$ Oil refining and pharmaceutical industries utilize solid catalysts with acidic properties. ${ }^{6-8} \mathrm{SO}_{4}{ }^{2-}, \mathrm{PO}_{4}{ }^{3-}, \mathrm{WO}_{4}{ }^{2-}$, $\mathrm{Cl}^{-}$and $\mathrm{F}^{-}$supported on metal oxides have been used to increase their thermal stability, mesoporosity, and more critically, the acidity level of such catalysts. ${ }^{\text {9-12 }}$ Most of the published works to date have been focused on $\mathrm{SO}_{4}{ }^{2-}$ - and $\mathrm{WO}_{4}{ }^{2-}$-supported metal oxide systems, ${ }^{\mathbf{1 3}-18}$ which have been found to be suitable for specific acid-catalyzed reactions. The acidity of such systems strongly depend on the preparation method. ${ }^{\mathbf{1 1 , 1 4 , 1 6}}$

A template pathway for preparing mesoporous materials is a novel process to produce materials with high activity for the synthesis of industrially relevant chemicals. ${ }^{19-22}$ Mesoporous materials are characterized by a high surface area, ordered pore channels, and large pore volume value. These advantages can facilitate active components achieving a highly dispersed state on the support, which raises their activity for reacting molecules. $^{23,24}$ For better performance, an efficient heterogeneous catalyst needs a higher acid strength level and density as well as thermal stability to minimize catalyst poisoning and leaching. Therefore, mesoporous materials, primarily metal oxides, have attracted growing interest as a support in the field of catalysis. ${ }^{25}$ Tin oxide is one of the most attractive functional materials because of its potential applications, mainly as a catalyst and as a carrier in supported catalysts. ${ }^{26}$ Besides its intrinsic nonstoichiometry and crystal defects, tin oxide nanoparticles can be used more efficiently as a catalyst due to the faster migration of the oxide ions within the $\mathrm{SnO}_{2}$ nanoparticles to increase the 
surface to volume ratio. Many authors have used high valence cations of metal oxide to promote the thermal stability and catalytic property of pure tin oxide. ${ }^{27,28}$ Therefore, it is of interest to study the novelties of phosphate-supported $\mathrm{SnO}_{2}$ as a solid acid catalyst. Various chemical routes have been used to synthesize nanoparticles of mesoporous metal oxides, e.g., precipitation, sol-gel, hydrothermal, microwave-assisted syntheses and ultrasonic spray pyrolysis. ${ }^{29,30}$ The addition of anion groups to a mesostructure metal oxide during the preparation methods prevent the sintering process and thus lead to improvements in their thermal stability and textural properties..$^{31,32}$

Further improvement is necessary, however, for the preparation of thermally stable mesoporous tin oxide. This process is still a challenge to researchers. ${ }^{., 33}$ Unlike sulfated metal oxides, phosphated metal oxides have received inadequate attention. Albeit, phosphate-based solid acids have proven quite efficacious in several industrially important acid-demanding reactions.

The present study aimed to adopt a phosphate-modified mesoporous tin oxide $\left(\mathrm{mSnO}_{2}\right)$ system as a catalyst. The modified catalytic systems $\left(\mathrm{H}_{3} \mathrm{PO}_{4} / \mathrm{m}-\mathrm{SnO}_{2}\right)$ were then applied to the preparation of hydroquinone diacetate, which is widely used as an ingredient for skin bleaching cream. DTA was used to systematically elucidate the physico-chemical properties of the $\mathrm{H}_{3} \mathrm{PO}_{4} / \mathrm{mSnO}_{2}$ catalysts, while TGA, XRD, TEM and FTIR techniques were applied for characterization, and the texture properties were determined from $\mathrm{N}_{2}$ adsorption at $-196^{\circ} \mathrm{C}$. The surface acidity was also examined.

\section{Results and discussion}

The thermograms of DTA and the TGA of dried $\mathrm{PO}_{4}{ }^{3-} / \mathrm{Sn}(\mathrm{OH})_{4}$ samples are shown in Fig. 1. The sample showed endothermic peaks at low temperature, which are assigned to the evolution of physically adsorbed water. The sample also showed two exothermic peaks. The first exothermic effect with a weight loss of $8.9 \mathrm{wt} \%$ at around $312{ }^{\circ} \mathrm{C}$ was attributed to the decomposition of the surfactant template and partial removal of the $\mathrm{OH}$ groups (dehydroxylation), ${ }^{\mathbf{3 4}, 35}$ while the second exothermic peak at $423{ }^{\circ} \mathrm{C}$ corresponded to a weight loss of $3.1 \mathrm{wt} \%$, which may be due to the crystallization of tin oxyhydroxide into tetragonal cassiterite $\mathrm{SnO}_{2} \cdot{ }^{36}$ In the case of $\mathrm{PO}_{4}{ }^{3-} / \mathrm{Sn}(\mathrm{OH})_{4}$ dried samples, the DTA in Fig. 2 shows exothermic peaks at $321{ }^{\circ} \mathrm{C}, 334{ }^{\circ} \mathrm{C}$ and $342{ }^{\circ} \mathrm{C}$ as the phosphate content increases for the $8 \%, 25 \%$ and $45 \% \mathrm{PO}_{4}{ }^{3-} / \mathrm{Sn}(\mathrm{OH})_{4}$ samples, respectively. Also, the exothermic peaks of the crystallization of tin oxyhydroxide into $\mathrm{mSnO}_{2}$ were also shifted to higher temperatures as the phosphate content increased, reaching $427{ }^{\circ} \mathrm{C}, 484{ }^{\circ} \mathrm{C}$ and $504{ }^{\circ} \mathrm{C}$ for the $8 \%, 25 \%$ and $45 \% \mathrm{PO}_{4}{ }^{3-} / \mathrm{mSnO}_{2}$ samples, respectively, indicating that the addition of phosphate to $\mathrm{mSnO}_{2}$ may enhance the surfactant-tin oxyhydroxide surface interaction, ${ }^{37}$ thus increasing the thermal stability of the tin oxyhydroxide phase and shifting its crystallization to higher temperature. These results show no effect that could be assigned to the decomposition of $\mathrm{PO}_{4}{ }^{3-}$ species, which was attributed to the thermal stability when treated with phosphoric acid. ${ }^{38}$

Fig. $2 \mathrm{~S}(\mathrm{~A}) \dagger$ shows the low-angle XRD patterns of $3 \%, 25 \%$, and $35 \% \mathrm{PO}_{4}{ }^{3-} / \mathrm{mSnO}_{2}$ samples heated at $400{ }^{\circ} \mathrm{C}$. The XRD curves exhibit one diffraction peak at $2 \theta=2.4^{\circ}$, corresponding to the (100) reflection, which was assigned to the presence of hexagonal mesostructured $\mathrm{SnO}_{2} \cdot{ }^{39,40}$ The same peak was observed for the calcined samples at $400{ }^{\circ} \mathrm{C}, 550{ }^{\circ} \mathrm{C}$ and $650{ }^{\circ} \mathrm{C}$ (Fig. $2 \mathrm{~S} \dagger$ ), which indicates that the presence of phosphate groups maintain the mesoporous structure of $\mathrm{mSnO}_{2}$.

Fig. 3A illustrates the wide-angle XRD patterns of $\mathrm{mSnO}_{2}$, and for the $3 \%, 25 \%$ and $35 \% \mathrm{PO}_{4}{ }^{3-} / \mathrm{mSnO}_{2}$ calcined at $400{ }^{\circ} \mathrm{C}$. The samples were found to display four well-distinguished peaks at $2 \theta=26.64^{\circ}, 33.91^{\circ}, 38.10^{\circ}$ and $51.74^{\circ}$, corresponding to the (110), (100), (200) and (211) reflection planes of a tetragonal cassiterite phase of $\mathrm{mSnO}_{2}$, respectively. The addition of $\mathrm{PO}_{4}{ }^{3-}$ to $\mathrm{mSnO}_{2}$ until $25 \mathrm{wt} \% \mathrm{PO}_{4}{ }^{3-}$ shows an XRD pattern similar to that of the pure $\mathrm{mSnO}_{2}$, indicating that the $\mathrm{PO}_{4}{ }^{3-}$ species exists as amorphous phosphate groups on the $\mathrm{mSnO}_{2}$ surface. ${ }^{41}$ When the loading of $\mathrm{PO}_{4}{ }^{3-}$ increased to $35 \mathrm{wt} \%$, a new reflection peak appears at $2 \theta=22.61^{\circ}$, which can be assigned to a layer-structured $\mathrm{SnP}_{2} \mathrm{O}_{7} \cdot{ }^{42}$ On the other hand, it is clear from Fig. 3B that the intensity of the diffraction peaks of the $3 \% \mathrm{PO}_{4}{ }^{3-} / \mathrm{mSnO}_{2}$ sample increases with the increase in the calcination temperature of the sample from $400{ }^{\circ} \mathrm{C}$ to $650{ }^{\circ} \mathrm{C}$,

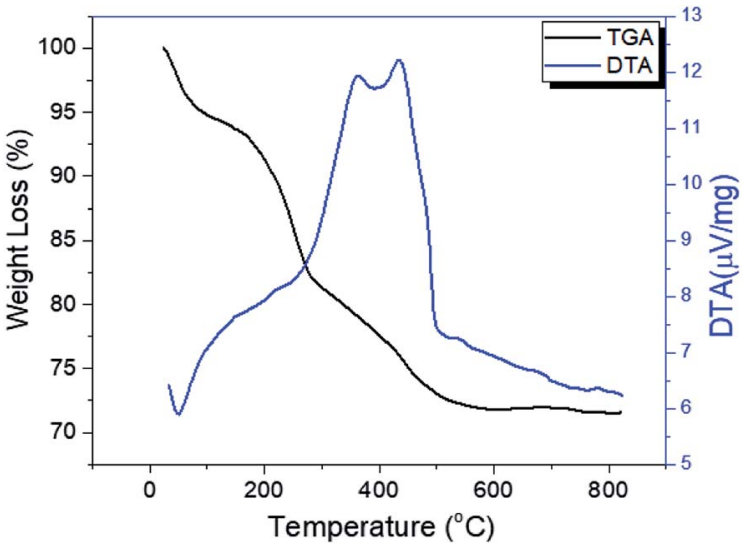

Fig. 1 DTA and TGA curves of dried $\mathrm{Sn}(\mathrm{OH})_{4}$.

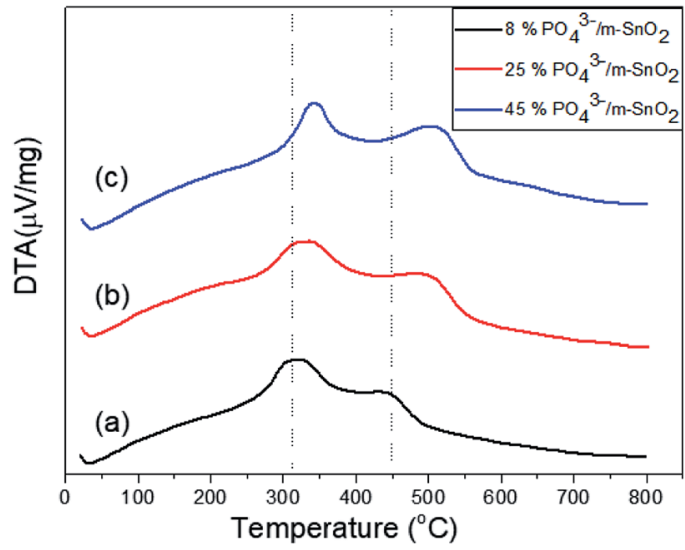

Fig. 2 DTA curves of (a) $8 \%$, (b) $25 \%$, (c) $45 \% \mathrm{PO}_{4}{ }^{3-} / \mathrm{m}-\mathrm{SnO}_{2}$ samples. 

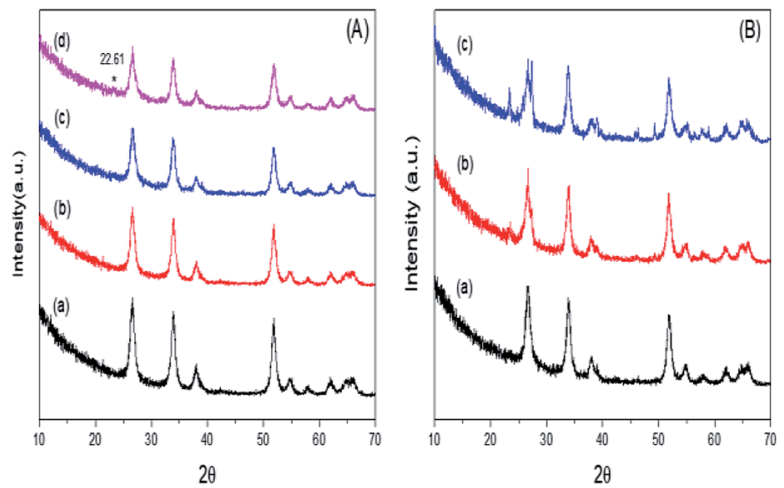

Fig. 3 (A) Wide-angle XRD pattern of (a) $\mathrm{m}-\mathrm{SnO}_{2}\left(400{ }^{\circ} \mathrm{C}\right.$ ) and the samples of $\mathrm{PO}_{4}{ }^{3-} / \mathrm{m}-\mathrm{SnO}_{2}\left(400{ }^{\circ} \mathrm{C}\right.$ ) at (b) $3 \%$, (c) $25 \%$, (d) $35 \%$, (B) wide-angle XRD patterns of the sample $3 \% \mathrm{PO}_{4}{ }^{3-} / \mathrm{m}-\mathrm{SnO}_{2}$ at (a) $400{ }^{\circ} \mathrm{C}$, (b) $550{ }^{\circ} \mathrm{C}$, (c) $650^{\circ} \mathrm{C}$.

which may be due to the increase in the dispersion of $\mathrm{PO}_{4}{ }^{3-}$ on the $\mathrm{mSnO}_{2}$ surface, which in turn increase the thermal stability of $\mathrm{mSnO}_{2}$, arising from the interaction of $\mathrm{PO}_{4}{ }^{3-}$ and $\mathrm{mSnO}_{2}$. The degree of crystallization of cassiterite $\mathrm{mSnO}_{2}$ gradually decreases with the increase in the phosphate content, while the width of the reflections is considerably broadened, indicating a small crystalline domain size (Table 1). The addition of phosphate anions to the template synthesis reaction medium of $\mathrm{mSn}(\mathrm{HO})_{4}$, substantially slows down the crystallization process via retarding the crystal size growth by occupying the defects on the surface of $\mathrm{mSn}(\mathrm{HO})_{4}{ }^{43}$ thus increasing its thermal stability and thus protecting the mesoporous structure from collapsing. ${ }^{41}$ The crystallite size data were determined from Xray diffraction and are listed in Table 1 , showing that the crystallite size of $\mathrm{PO}_{4}{ }^{3-} / \mathrm{mSnO}_{2}$ is smaller in comparison to the pure $\mathrm{mSnO}_{2}$ nanocrystalline $(13.70-11.30 \mathrm{~nm})$. Furthermore, the crystallite size of $3 \% \mathrm{PO}_{4}{ }^{3-} / \mathrm{mSnO}_{2}$ increases from 12.17 to $16.66 \mathrm{~nm}$ with the increase in calcination temperature (400-650 ${ }^{\circ} \mathrm{C}$ ), which indicates that pure $\mathrm{mSnO}_{2}$ and $\mathrm{PO}_{4}{ }^{3-} / \mathrm{mSnO}_{2}$ are present in the nanoscale. In the phosphate sample annealed between $400{ }^{\circ} \mathrm{C}$ and $650{ }^{\circ} \mathrm{C}$, the crystallite size slightly changes from 13.70 to $16.66 \mathrm{~nm}$, suggesting that the $\mathrm{PO}_{4}$ species remain bonded to the $\mathrm{mSnO}_{2}$ surface, stabilizing it against sintering. It was reported that the order of the mesostructured materials strongly depends on the texture properties of the pores. ${ }^{44} \mathrm{An}$ analogous phenomenon was observed with $\mathrm{TiO}_{2}, \mathrm{ZrO}_{2}$ and $\mathrm{Fe}_{2} \mathrm{O}_{3} \cdot{ }^{44,45}$

TEM images of $\mathrm{mSnO}_{2}$ show an ordered structure with a uniform mesoporous arrangement into hexagons (Fig. 4a). It

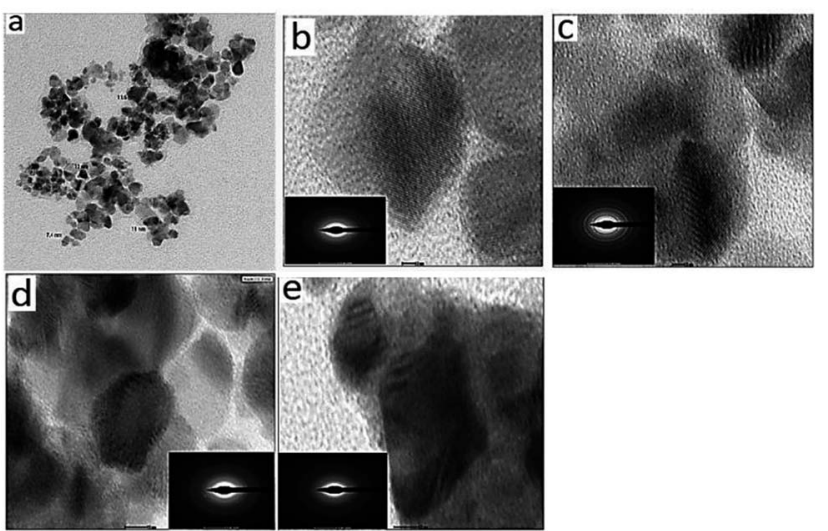

Fig. 4 TEM images of (a) $\mathrm{mSnO}_{2}$ calcined at $550{ }^{\circ} \mathrm{C}$, (b) $3 \% \mathrm{PO}_{4}{ }^{3-} / \mathrm{m}$ $\mathrm{SnO}_{2}$ calcined at $400{ }^{\circ} \mathrm{C}$, (c) $3 \% \mathrm{PO}_{4}{ }^{3-} / \mathrm{m}-\mathrm{SnO}_{2}$ calcined at $550{ }^{\circ} \mathrm{C}$, (d) $8 \% \mathrm{PO}_{4}{ }^{3-} / \mathrm{m}-\mathrm{SnO}_{2}$ calcined at $400{ }^{\circ} \mathrm{C}$ and (e) $25 \% \mathrm{PO}_{4}{ }^{3-} / \mathrm{m}-\mathrm{SnO}_{2}$ calcined at $400{ }^{\circ} \mathrm{C}$

is apparent that $\mathrm{mSnO}_{2}$ has a significant void fraction, which may be due to the mesoporous structure of $\mathrm{SnO}_{2}$, and concomitantly a rather low density. Fig. $4 \mathrm{c}-\mathrm{e}$ show the TEM images of the $3 \%, 8 \%$ and $25 \% \mathrm{PO}_{4}{ }^{3-} / \mathrm{mSnO}_{2}$ catalysts, which indicate that when $\mathrm{PO}_{4}{ }^{3-}$ species are loaded on $\mathrm{mSnO}_{2}$ calcined at $400{ }^{\circ} \mathrm{C}$, the lattice retains the ordered mesoporous channels and the $\mathrm{PO}_{4}{ }^{3-}$ groups are embedded uniformly into the $\mathrm{mSnO}_{2}$ framework without disordering the mesostructured framework. The selected area electron diffraction (SAED) pattern images (insets) of the samples exhibit diffraction rings attributed to the polycrystalline behaviour of the $\mathrm{mSnO}_{2}$, while the crystallite degrees of the $3 \%, 8 \%$ and $25 \% \mathrm{PO}_{4}{ }^{3-} / \mathrm{mSnO}_{2}$ catalysts decrease with the increase in $\mathrm{PO}_{4}{ }^{3-}$ content. ${ }^{46,47}$ The TEM images of $3 \%$ $\mathrm{PO}_{4}{ }^{3-} / \mathrm{mSnO}_{2}$ calcined at $550{ }^{\circ} \mathrm{C}$ (Fig. $4 \mathrm{~b}$ ) illustrate that the mesoporous structure remains even after calcination at $550{ }^{\circ} \mathrm{C}$, which reflects the role of the phosphate groups in improving the thermal stability of the tin oxide. ${ }^{47}$ It is clear from the TEM images that the dark colour and the area occupied by the phosphate group both increase with both the phosphate content and the calcination temperature, indicating the great dispersion of phosphate groups on the mesoporous $\mathrm{SnO}_{2}$ surfaces. Also, the side images (inset) show an increase in the crystalline size with increasing calcination temperature, which is in a good agreement with the results from the XRD analysis.

The FTIR spectra of the $\mathrm{mSnO}_{2} 550{ }^{\circ} \mathrm{C}, x \mathrm{PO}_{4}{ }^{3-} / \mathrm{mSnO}_{2}$ and $3 \mathrm{PO}_{4}{ }^{3-} / \mathrm{mSnO}_{2}$ samples calcined at different temperatures are shown in Fig. $5 \mathrm{~A}$ and B. The band at $1625 \mathrm{~cm}^{-1}$ appearing in the

Table 1 Comparison of the structural parameters of $\mathrm{mSnO}_{2}$ and various $\mathrm{PO}_{4}{ }^{3-} / \mathrm{mSnO}_{2}$ samples

\begin{tabular}{lllll}
\hline Samples & $D(\mathrm{~nm})$ & $d_{100}(\mathrm{~nm})$ & $d_{\text {pore, BJH }}(\mathrm{nm})$ & $a^{0}(\mathrm{~nm})$ \\
\hline $\mathrm{mSnO}_{2}{ }^{-400}$ & 13.70 & 3.62 & 3.22 & 4.18 \\
$3 \% \mathrm{PO}_{4}{ }^{3-} / \mathrm{mSnO}_{2}-400$ & 12.17 & 3.63 & 3.15 & 0.96 \\
$25 \% \mathrm{PO}_{4}{ }^{3-} / \mathrm{mSnO}_{2}-400$ & 11.87 & 3.66 & 2.66 & 4.19 \\
$35 \% \mathrm{PO}_{4}{ }^{3-} / \mathrm{mSnO}_{2}-400$ & 11.30 & 3.69 & 2.52 & 4.23 \\
$3 \% \mathrm{PO}_{4}{ }^{3-} / \mathrm{mSnO}_{2}-550$ & 14.50 & 3.60 & 3.41 & 4.16 \\
$3 \% \mathrm{PO}_{4}{ }^{3-} / \mathrm{mSnO}_{2}-650$ & 16.66 & 3.57 & 3.82 & 1.74 \\
\end{tabular}


spectra of the samples even after calcination at different temperatures corresponds to the $\mathrm{OH}$ bending vibrations. The FTIR spectra of phosphate $\mathrm{mSnO}_{2}$ generally show absorption bands at 1035 and 1150, 1360, 1410 and $1520 \mathrm{~cm}^{-1}$. The absorption bands at 1360, 1410 and $1520 \mathrm{~cm}^{-1}$ could be assigned to $\mathrm{P}-\mathrm{O}$ stretching frequency bonds in which their order is close to two $\mathrm{P}=\mathrm{O}$, phosphoryl groups. ${ }^{48}$ By increasing the temperature to $650{ }^{\circ} \mathrm{C}$, the broadband at $1550-1300 \mathrm{~cm}^{-1}$ is reduced to one sharp band and one shoulder, due to the formation of bidentate-bound phosphate ions $\left(\mathrm{C}_{2} \mathrm{~V}\right.$ point group). The band at 1035 and the shoulder at $1150 \mathrm{~cm}^{-1}$ are frequencies for $\mathrm{PO}_{4}{ }^{3-}$ and the position of such a fundamental band was observed in phosphated zirconia. ${ }^{49}$ The fading of the shoulder and the presence of a broad and sharp band located at $1055 \mathrm{~cm}^{-1}$ when the $\mathrm{PO}_{4}{ }^{3-}$ content was increased to $45 \mathrm{wt} \%$ may be due to the dropping of the symmetry in the free $\mathrm{PO}_{4}{ }^{3-}$ (Td point group) to either $\mathrm{C}_{3} \mathrm{~V}$ or $\mathrm{C}_{2} \mathrm{~V}^{48}$ This may be due to the $\mathrm{PO}_{4}{ }^{3-}$ groups being bound to the tin oxide surface and being distributed homogeneously. ${ }^{50,51}$ Here, the $1055 \mathrm{~cm}^{-1}$ band is divided into two bands at 1035 and $1150 \mathrm{~cm}^{-1}$ at $650{ }^{\circ} \mathrm{C}$, which could be assigned to the bidentate bound phosphate ions $\left(\mathrm{C}_{2} \mathrm{~V}\right.$ point group), which motivate the polymerization of the $\mathrm{HPO}_{4}{ }^{2-}$ groups into $\mathrm{P}_{2} \mathrm{O}_{7}{ }^{4-}$, which is in a good agreement with the appearance of a new peak due to $\mathrm{SnP}_{2} \mathrm{O}_{7}$ in the X-ray pattern (Fig. 3A).

These results indicate that phosphate groups are chemically adsorbed on the surface of $\mathrm{mSnO}_{2}$ and still exist on the surface even after calcination of the samples at high temperatures. The mechanism, as explained in Scheme 1, follows the dehydroxylation reaction of $\mathrm{P} / \mathrm{mSnO}_{2}$ samples, with amorphous $\mathrm{Sn}\left(\mathrm{HPO}_{4}\right)_{2}$ formed on the surface, which is further heated to form tin pyrophosphate, $\mathrm{SnP}_{2} \mathrm{O}_{7}$, which is in a good agreement with the XRD pattern at $650^{\circ} \mathrm{C}$.

Fig. 6 shows the nitrogen adsorption-desorption isotherms of some representative samples of $\mathrm{PO}_{4}{ }^{3-} / \mathrm{mSnO}_{2}$, in which the isotherms exhibit a type IV feature, which is a characteristic feature of mesoporous materials..$^{52}$ Barrett-Joyner-Halenda $(\mathrm{BJH})$ analysis demonstrated that the average pore diameter $\left(d_{\text {pore,BjH }}\right)$ of $\mathrm{mSnO}_{2}$ calcined at $550{ }^{\circ} \mathrm{C}$ was $13.21 \mathrm{~nm}$ (Table 1). The $d_{\text {pore, ВJH }}$ of $\mathrm{PO}_{4}{ }^{3-} / \mathrm{mSnO}_{2}$ samples was found to decrease
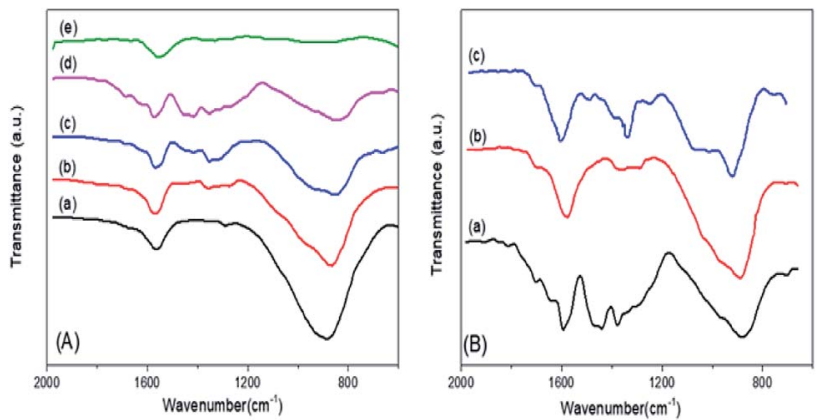

Fig. 5 (A) FTIR spectra of (a) $\mathrm{m}-\mathrm{SnO}_{2}\left(550{ }^{\circ} \mathrm{C}\right.$ ) and (b) $3 \%$, (c) $25 \%$, (d) $35 \%$, (e) $45 \% \mathrm{PO}_{4}{ }^{3-} / \mathrm{m}-\mathrm{SnO}_{2}$ catalysts calcined at $550{ }^{\circ} \mathrm{C}$. (B) FTIR spectra of $3 \% \mathrm{PO}_{4}{ }^{3-} / \mathrm{m}-\mathrm{SnO}_{2}$ calcined at: (a) $450{ }^{\circ} \mathrm{C}$, (b) $550{ }^{\circ} \mathrm{C}$, (c) $650{ }^{\circ} \mathrm{C}$.

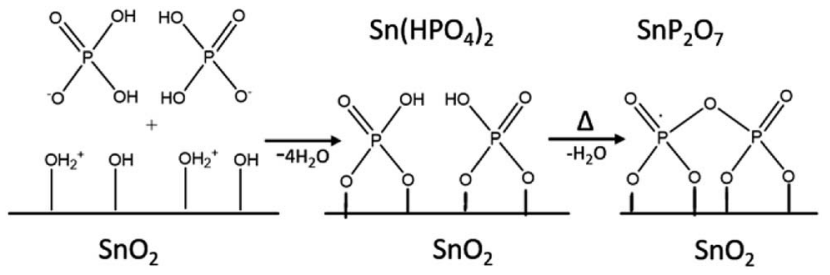

Scheme 1 Formation of $\mathrm{PO}_{4}{ }^{3-} / \mathrm{mSnO}_{2}$.

with the increase in phosphate content from 3.15 to $2.52 \mathrm{~nm}$ (Table 1). The approximate thickness of the porous wall $\left(t_{\text {wall }}\right)$ calculated from the difference between the hexagonal unit cell parameter $\left(a^{0}=2 d_{100} / \sqrt{ } 3\right)$ and $d_{\text {pore,BjH }}$ (Table 1$)$, after calcination at $400{ }^{\circ} \mathrm{C} t_{\text {wall }}$ increased with increasing the phosphate content from $0.96 \mathrm{~nm}$ for $\mathrm{mSnO}_{2}$ to $1.74 \mathrm{~nm}$ for the $35 \% \mathrm{PO}_{4}{ }^{3-} /$ $\mathrm{mSnO}_{2}$ samples. The $d_{\text {pore,BJH }}$ and $t_{\text {wall }}$ values decreased with the calcination temperature. On the other hand, the values of $d_{110^{-}}$-spacing and $a^{0}$ were found to decrease with the increase in calcination temperature, which may indicate that some changes occur on the mesostructure as the calcination temperature of $\mathrm{PO}_{4}{ }^{3-} / \mathrm{mSnO}_{2}$ increases. The values of $S_{\mathrm{BET}}$, as shown in Table 2, increase gradually with the rise of $\mathrm{PO}_{4}{ }^{3-}$ content to reach a maximum for $25 \% \mathrm{PO}_{4}{ }^{3-} / \mathrm{mSnO}_{2}$. This amount was optimal to form a monolayer, and the values of $S_{\mathrm{BET}}$ decreased with further increases of the $\mathrm{PO}_{4}{ }^{3-}$ content.

Moreover, the $S_{\mathrm{BET}}$ values were found to decrease when the calcination temperature increased up to $650{ }^{\circ} \mathrm{C} .{ }^{50,51}$ The increase in the surface area values of $\mathrm{PO}_{4}{ }^{3-} / \mathrm{mSnO}_{2}$ over that of $\mathrm{mSnO}_{2}$ may be due to the formation of two-dimensional surface layers from $\mathrm{Sn}-\mathrm{PO}_{4}{ }^{3-}$, which stabilize the defects and inhibit the collapsing of the $\mathrm{mSnO}_{2}$ surface, ${ }^{53}$ which also explains the role of $\mathrm{PO}_{4}{ }^{3-}$ in enhancing the porous structure of $\mathrm{PO}_{4}{ }^{3-} / \mathrm{mSnO}_{2}$. The increase in $\mathrm{PO}_{4}{ }^{3-}$ content beyond $25 \mathrm{wt} \%$ led to the production of more phosphate layers and/or the phosphate groups attacking the pore mouths blocking them, and consequently the surface area values decreased. ${ }^{54,55}$ The above results suggest that the interaction between $\mathrm{PO}_{4}{ }^{3-}$ and $\mathrm{mSnO}_{2}$ crystallites not only stabilizes the crystallite structure in lower dimensions, but also it keeps phosphate groups at the $\mathrm{SnO}_{2}$ surfaces, inhibiting the crystallite aggregation and acting as a structure progeny director mediating nanoparticle growth and assembly and stabilizing the mesostructure walls and
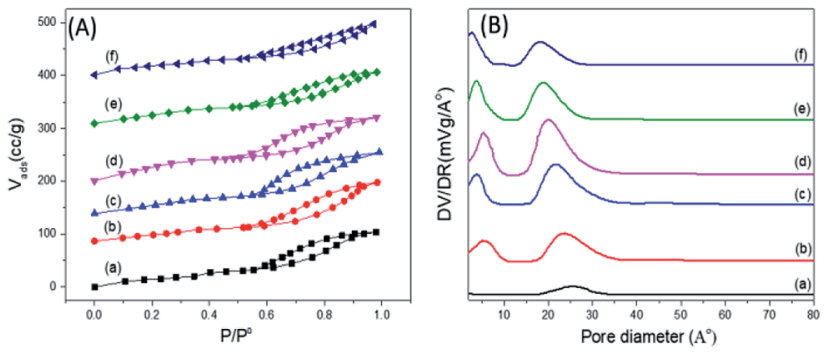

Fig. 6 (A) Adsorption-desorption isotherms of nitrogen at $-196^{\circ} \mathrm{C}$ (B) pore size distributions for $\mathrm{PO}_{4}{ }^{3-} / \mathrm{m}-\mathrm{SnO}_{2}$ at (a) $3 \%$, (b) $8 \%$, (c) $18 \%$, (d) $25 \%$, (e) $35 \%$, (f) $45 \%$ calcined at $400{ }^{\circ} \mathrm{C}$. 
Table 2 Surface characteristics of $\mathrm{PO}_{4}{ }^{3-} / \mathrm{m}-\mathrm{SnO}_{2}$ catalysts

\begin{tabular}{|c|c|c|c|c|}
\hline Catalyst & $T\left({ }^{\circ} \mathrm{C}\right)$ & $S_{\mathrm{BET}} \mathrm{m}^{2} \mathrm{~g}^{-1}$ & $d_{\text {pore,ВJH }}(\mathrm{nm})$ & $\mathrm{VT} \mathrm{ml} \mathrm{g}^{-1}$ \\
\hline $\mathrm{m}-\mathrm{SnO}_{2}$ & 550 & 29 & 3.22 & 0.13 \\
\hline $3 \% \mathrm{PO}_{4}{ }^{3-} / \mathrm{m}-\mathrm{SnO}_{2}$ & 400 & 65 & 3.15 & 0.16 \\
\hline $8 \% \mathrm{PO}_{4}{ }^{3-} / \mathrm{m}-\mathrm{SnO}_{2}$ & 400 & 95 & 2.96 & 0.17 \\
\hline $18 \% \mathrm{PO}_{4}{ }^{3-} / \mathrm{m}-\mathrm{SnO}_{2}$ & 400 & 130 & 2.81 & 0.18 \\
\hline $25 \% \mathrm{PO}_{4}{ }^{3-} / \mathrm{m}-\mathrm{SnO}_{2}$ & 400 & 155 & 2.66 & 0.18 \\
\hline $35 \% \mathrm{PO}_{4}{ }^{3-} / \mathrm{m}-\mathrm{SnO}_{2}$ & 400 & 113 & 2.52 & 0.14 \\
\hline $45 \% \mathrm{PO}_{4}{ }^{3-} / \mathrm{m}-\mathrm{SnO}_{2}$ & 400 & 75 & 2.46 & 0.14 \\
\hline $3 \% \mathrm{PO}_{4}{ }^{3-} / \mathrm{m}-\mathrm{SnO}_{2}$ & 450 & 63 & 3.35 & 0.15 \\
\hline $3 \% \mathrm{PO}_{4}{ }^{3-} / \mathrm{m}-\mathrm{SnO}_{2}$ & 550 & 56 & 3.41 & 0.15 \\
\hline $3 \% \mathrm{PO}_{4}{ }^{3-} / \mathrm{m}-\mathrm{SnO}_{2}$ & 650 & 41 & 3.82 & 0.14 \\
\hline
\end{tabular}

increasing the thermal stability. ${ }^{56}$ Again, the increase in surface area and pore volume and the decrease in the average pore diameter of the $3 \%$ to $25 \% \mathrm{PO}_{4}{ }^{3-} / \mathrm{mSnO}_{2}$ samples over pure $\mathrm{mSnO}_{2}$ with increasing the phosphate content indicate a relatively high thermal stability of the prepared samples. The decrease in the pore volume and $d_{\text {pore,BJH }}$ upon increasing the phosphate content over $25 \mathrm{wt} \%$ may be due to the formation of multi-phosphate layers, as proposed in Scheme 1, whereby the surface hydroxyl groups of $\mathrm{Sn}(\mathrm{OH})_{4}$ are replaced by phosphate groups and therefore there is an increased energy barrier and less crystal growth sites, consequently inhibiting the crystal growth.

The samples showed a bimodal pore size distribution consisting of smaller and larger interparticle pores, as illustrated in Fig. 6B. The addition of $\mathrm{PO}_{4}{ }^{3-}$ to $\mathrm{mSnO}_{2}$ was associated with an increase in the number of mesopores and micropores, as evident from the increase in the height of the distribution maxima and slight shift to lower $\mathrm{rH}$ values until a maximum at $25 \mathrm{wt} \%$ phosphate was reached, where it begins to decrease. Upon increasing the calcination temperature, (Fig. $3 S_{\dagger} \dagger$ ), both the smaller and larger interparticle pores decreased, which is in line with the decrease in the surface (Table 2). The width of the mesopore type increased with phosphate content, which confirmed the role of $\mathrm{PO}_{4}{ }^{3-}$ in increasing the porosity of $\mathrm{mSnO}_{2}{ }^{56}$

The nonaqueous potentiometric titration curves of $n$-butylamine of Fig. $4 \mathrm{~S} \dagger$ were used to calculate the total number of acid sites and the acid strength of the $\mathrm{PO}_{4}{ }^{3-} / \mathrm{mSnO}_{2}$ catalysts. ${ }^{57,58} \mathrm{As}$ evident from Fig. $4 \mathrm{~S} \uparrow$ and the data in Table 3 , the acidity and the acid strength values of $\mathrm{PO}_{4}{ }^{3-} / \mathrm{mSnO}_{2}$ changed with the phosphate loading and reached their maximum value for $25 \%$ $\mathrm{PO}_{4}{ }^{3-} / \mathrm{mSnO}_{2}(\mathrm{Ei}=+480.6 \mathrm{mV})$ calcined at $400{ }^{\circ} \mathrm{C}$, which may be due to the completion of a bidentate phosphate monolayer on the tin oxide surface, as evident from the FTIR data. The decrease in the total acidity and the acid strength upon increasing the $\mathrm{PO}_{4}{ }^{3-}$ loading may be due to the formation of more phosphate layers on the $\mathrm{mSnO}_{2}$ surface. The calcination temperature $400{ }^{\circ} \mathrm{C}$ was the most suitable calcination temperature for the generation of strong acidic sites.

The loss of surface acidity at higher calcination temperatures up to $650^{\circ} \mathrm{C}$ may be due to the loss of $\mathrm{H}^{+}$by dehydration with the surface $\mathrm{OH}$ or $\mathrm{OH}$ of the next phosphate groups, forming a bridging phosphate group on the surface, as shown in Scheme 1 , which causes a reduction in acidic hydrogen and a decrease in the total acidity.

Pyridine adsorption on the $\mathrm{PO}_{4}{ }^{3-} / \mathrm{mSnO}_{2}$ samples was used to specify the Brönsted (B) and Lewis (L) acid sites on the sample surfaces. The FTIR spectra of pyridine adsorbed over the Brönsted (B) and Lewis (L) acid sites of the samples are shown in Fig. 7A and B. Bands at around 1444 and $1452 \mathrm{~cm}^{-1}$ were characteristic of pyridine adsorbed on Lewis acid sites. ${ }^{59}$ The bands at 1536 and $1553 \mathrm{~cm}^{-1}$ were due to the pyridinium ion adsorbed on Brönsted acid sites. ${ }^{60}$ Moreover, other FTIR bands appear at 1484 and $1503 \mathrm{~cm}^{-1}$, attributed to the overlap of Lewis and Brönsted acid sites. ${ }^{61}$ The integrated areas of the bands at 1536 and $1452 \mathrm{~cm}^{-1}$ were used to calculate the number of Brönsted and Lewis acid sites. It was evident from Fig. 7C that the samples have Brönsted and Lewis acid sites and these increase with the increase in phosphate loading up to $25 \%$ $\mathrm{PO}_{4}{ }^{3-} / \mathrm{mSnO}_{2}$, and then decrease with further increases in $\mathrm{PO}_{4}{ }^{3-}$ loading above $25 \mathrm{wt} \%$. Moreover, the number of Brönsted and Lewis acid sites decreases gradually with the increase in calcination temperature over $400{ }^{\circ} \mathrm{C}$ (Table 3). The surface distribution and interaction of phosphate species with the $\mathrm{SnO}_{2}$ surface increase the number of Brönsted and Lewis acid sites. In analogy with sulfated tin oxide, ${ }^{62}$ the increase in Lewis acidity by phosphate loading may be due to the formation of a tin oxide surface phosphorus complex containing $\mathrm{P}=\mathrm{O}$ covalent bonds, and so the inductive effect of these covalent bonds of $\mathrm{P}=\mathrm{O}$ strengthen the Lewis acid character of the sample, as suggested in Scheme 2. ${ }^{63,64} \mathrm{Fig} .5 \mathrm{~S} \dagger$ shows the $\mathrm{NH}_{3}$-TPD results for the pure $\mathrm{m}-\mathrm{SnO}_{2}$ calcined at $400{ }^{\circ} \mathrm{C}$, which shows a broad peak of $\mathrm{NH}_{3}$ desorption at $240{ }^{\circ} \mathrm{C}$, which indicates the presence of weak acid sites. After modifying the $\mathrm{mSnO}_{2}$ with $\mathrm{PO}_{4}{ }^{3-}$, this peak starts to disappear and two peaks start to appear at $334{ }^{\circ} \mathrm{C}$ and $440{ }^{\circ} \mathrm{C}$, corresponding to moderate and strong acid sites, respectively. For $45 \% \mathrm{PO}_{4}{ }^{3-}$, only one peak at $440{ }^{\circ} \mathrm{C}$ is seen, corresponding to the strong acid sites due to the saturation of the surface with the $\mathrm{PO}_{4}{ }^{3-}$ groups. ${ }^{26}$

Fig. $8 \mathrm{~A}$ and $\mathrm{B}$ show the effect of the phosphate content and consequently, the number of Brönsted and Lewis acid sites on the $\%$ formation of hydroquinone diacetate compound. As can be seen, the \% yield of hydroquinone diacetate compound increases gradually with the increase in $\mathrm{PO}_{4}{ }^{3-}$ loading on $\mathrm{mSnO}_{2}$ until it reaches a maximum value of $93.2 \%$ for the $25 \%$ $\mathrm{PO}_{4}{ }^{3-} / \mathrm{mSnO}_{2}$ catalyst with a selectivity of $100 \%$. The surface acidity and acid strength of $\mathrm{PO}_{4}{ }^{3-} / \mathrm{mSnO}_{2}$ are enhanced and attain a maximum at $25 \mathrm{wt} \% \mathrm{PO}_{4}{ }^{3-}$. Moreover, the Brönsted and Lewis acid sites change with the same trend as the formation of hydroquinone diacetate compound, which may indicate that Lewis and/or Brönsted acid sites can catalyse the formation of hydroquinone diacetate compound. No activity was observed for pure $\mathrm{mSnO}_{2}$, which may be due to its low acidity and site strength $(+74 \mathrm{mV})$. As evident from Table 3 and Scheme 2, increasing the calcination temperature from $400{ }^{\circ} \mathrm{C}$ to $650{ }^{\circ} \mathrm{C}$ lead to a decrease in the catalytic activity, which is in line with the decrease in surface area and the decrease of the number of Brönsted and Lewis acid sites. The calcination temperature is an essential aspect in the synthesis of phosphated metal oxide 
Table 3 Acidity characteristics of $\mathrm{PO}_{4}{ }^{3-} / \mathrm{m}-\mathrm{SnO}_{2}$ catalysts

\begin{tabular}{|c|c|c|c|c|c|c|}
\hline Catalyst & $T\left({ }^{\circ} \mathrm{C}\right)$ & $\mathrm{Ei}(\mathrm{mV})$ & No. of acid sites $/ g \times 10^{-19}$ & $\mathrm{~B} / \mathrm{L}$ & Conversion\% & TOF $h^{-1}$ \\
\hline $\mathrm{m}-\mathrm{SnO}_{2}$ & 400 & 74 & 0.84 & 0.54 & 0 & 0 \\
\hline $3 \% \mathrm{PO}_{4}{ }^{3-} / \mathrm{m}-\mathrm{SnO}_{2}$ & 400 & 320.4 & 0.96 & 1.04 & 8.6 & 222.88 \\
\hline $18 \% \mathrm{PO}_{4}{ }^{3-} / \mathrm{m}-\mathrm{SnO}_{2}$ & 400 & 450.7 & 1.20 & 1.12 & 87.7 & 1818.31 \\
\hline $25 \% \mathrm{PO}_{4}{ }^{3-} / \mathrm{m}-\mathrm{SnO}_{2}$ & 400 & 480.6 & 1.33 & 1.68 & 93.2 & 1743.47 \\
\hline $35 \% \mathrm{PO}_{4}{ }^{3-} / \mathrm{m}-\mathrm{SnO}_{2}$ & 400 & 421.8 & 0.96 & 1.14 & 80.4 & 2083.70 \\
\hline $25 \% \mathrm{PO}_{4}{ }^{3-} / \mathrm{m}-\mathrm{SnO}_{2}$ & 550 & 274.6 & 0.84 & 1.52 & 61.6 & 1824.53 \\
\hline $25 \% \mathrm{PO}_{4}{ }^{3-} / \mathrm{m}-\mathrm{SnO}_{2}$ & 650 & 203.5 & 0.78 & 1.36 & 30.5 & 972.87 \\
\hline
\end{tabular}
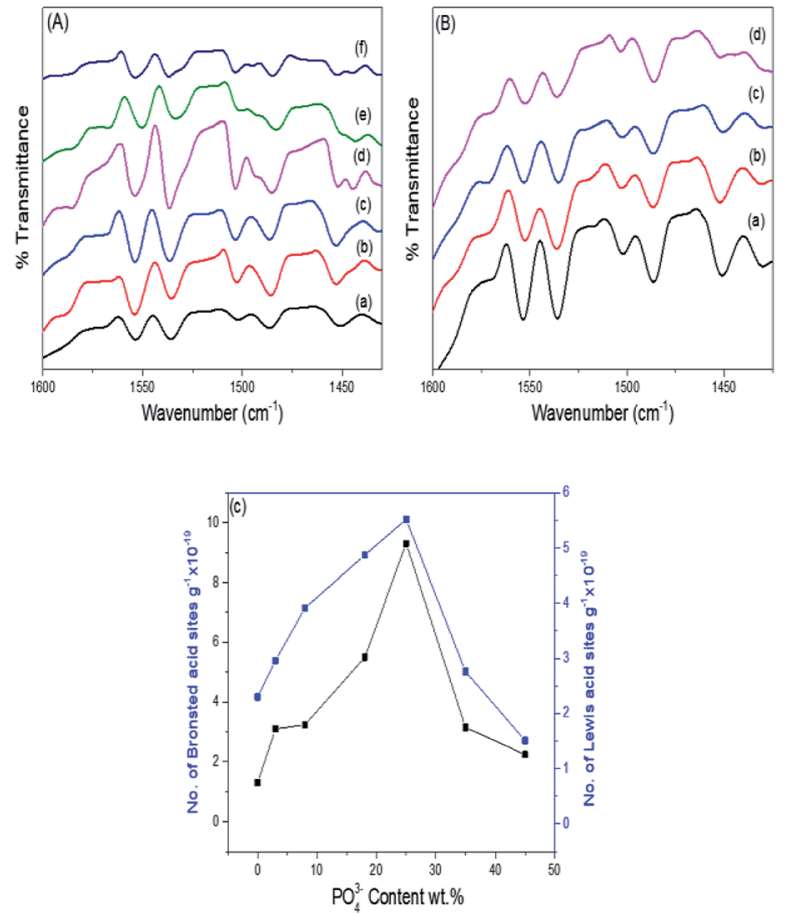

Fig. 7 (A) FTIR spectra of pyridine adsorbed on (a) $3 \%$, (b) $8 \%$, (c) $18 \%$, (d) $25 \%$, (e) $35 \%$, (f) $45 \% \mathrm{PO}_{4}{ }^{3-} / \mathrm{m}-\mathrm{SnO}_{2}$ calcined at $400{ }^{\circ} \mathrm{C}$. (B) FTIR spectra of pyridine adsorbed on the $25 \% \mathrm{PO}_{4}{ }^{3-} / \mathrm{m}-\mathrm{SnO}_{2}$ sample calcined at (a) $400^{\circ} \mathrm{C}$, (b) $450^{\circ} \mathrm{C}$, (c) $550^{\circ} \mathrm{C}$ and (d) $650^{\circ} \mathrm{C}$. (C) Effect of $\mathrm{PO}_{4}{ }^{3-}$ content on the number of Brönsted and Lewis acid sites.

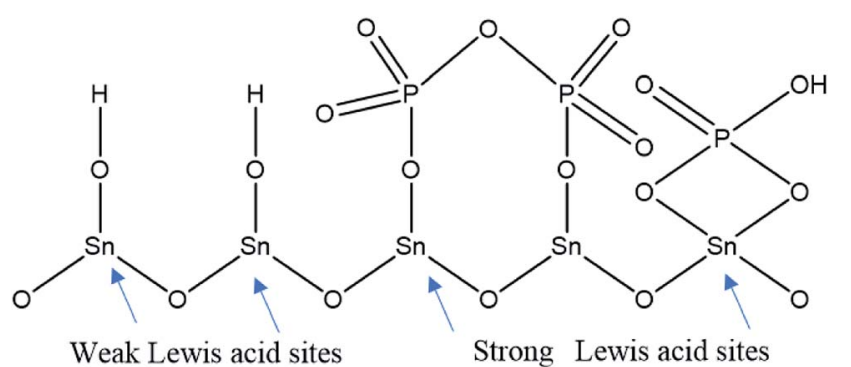

Weak Lewis acid sites
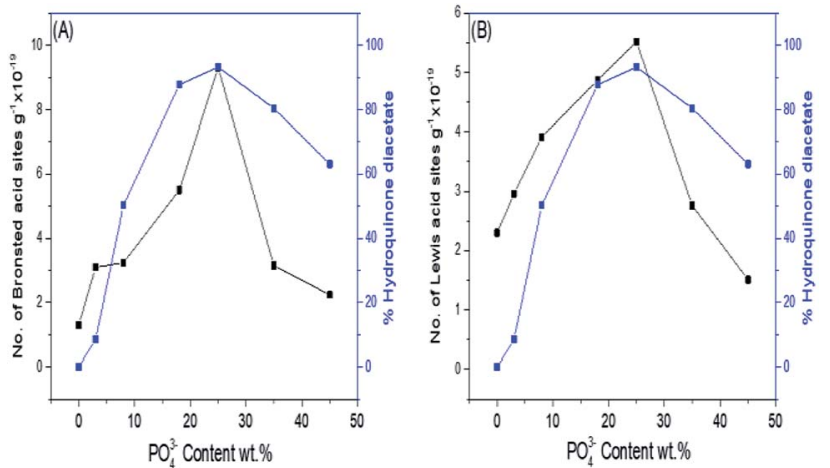

Fig. 8 (A) Effect of $\mathrm{PO}_{4}{ }^{3-}$ content $\mathrm{wt} \% / \mathrm{mSnO}_{2}$ calcined at $400{ }^{\circ} \mathrm{C}$ on the number of Brönsted acid sites and \% hydroquinone diacetate. (B) Effect of $\mathrm{PO}_{4}{ }^{3-}$ content $w \mathrm{wt} / \mathrm{mSnO}_{2}$ calcined at $400{ }^{\circ} \mathrm{C}$ on the number of Lewis acid sites and \% hydroquinone diacetate.

catalyst due to its role in the interaction between the metal oxide surface and phosphate groups for the generation of active acid sites. The optimum operating conditions for an anionmetal oxide catalyst was found to depend on the type of metal oxides, supported anions and the calcination temperature. ${ }^{52}$

It was observed that with increasing the molar ratio from $1: 1$ to $1: 2$ and $1: 3$, the \% yield of hydroquinone diacetate increased gently from $60.2 \%$, to $77.5 \%$ to $93.2 \%$, respectively, with $100 \%$ selectivity. However, a further increase in the acetic anhydride molar content was accompanied by a decrease in the percentage yield of hydroquinone diacetate to $83.1 \%$ (molar ratio $1: 4)$. As acetic anhydride acts as both a solvent and reactant, an excess of acetic anhydride is used to facilitate the reaction until the molar ratio of hydroquinone to acetic anhydride is $1: 3$. Many factors may affect the catalyst activity; the dilution effect of acetic anhydride (solvent effect) and/or the catalyst active sites may be blocked due to a higher acetic anhydride concentration, thereby decreasing the yield of hydroquinone diacetate. Because the activation of acetic anhydride is the key step in the formation of hydroquinone diacetate, the decrease in \% yield of hydroquinone diacetate may be due to the presence of low (molar ratio $1: 1$ and $1: 2$ ) or excess (molar ratio 1:4) activated acetic anhydride - Brönsted acid sites and/or activated acetic anhydride - Lewis acid sites

Scheme 2 Lewis acid on $\mathrm{PO}_{4}{ }^{3-} / \mathrm{mSnO}_{2}$. 


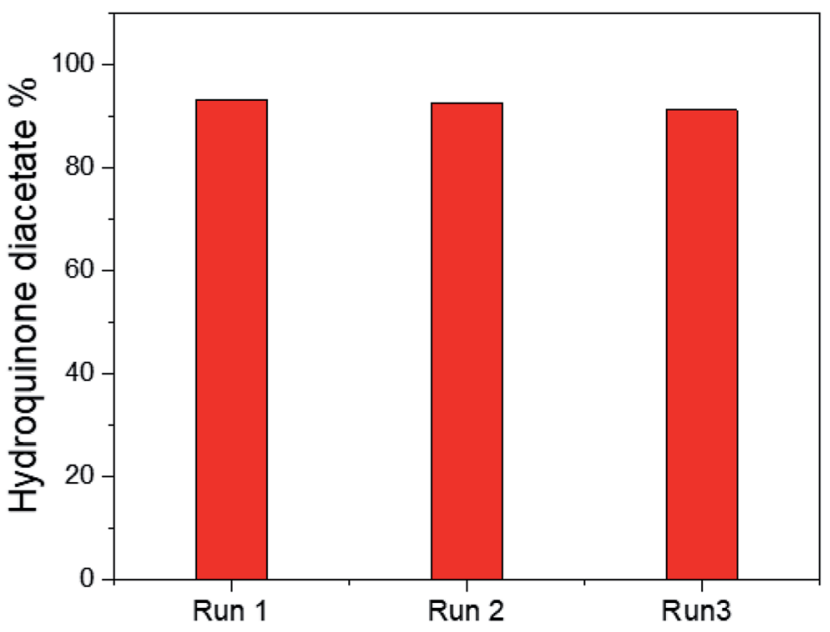

Fig. 9 Reusability test for $25 \% \mathrm{PO}_{4}{ }^{3-} / \mathrm{mSnO}_{2}$.

intermediates. Therefore, 1:3 molar ratio of reactants was considered optimum for the further studies.

The reusability of the $25 \% \mathrm{PO}_{4}{ }^{3-} / \mathrm{mSnO}_{2}$ catalyst was checked with three consecutive experiments by using the recovered catalyst. The catalyst was separated by filtration, washed with acetone several times and dried overnight at $100{ }^{\circ} \mathrm{C}$. The reaction was reperformed on this reactivated catalyst. It was observed that there was no significant loss in activity, as shown in Fig. 9, and the catalytic activity of the catalyst was 93.2\%, 92.4\% and 91.1\%, respectively. Moreover Fig. 7SA and $\mathrm{B} \uparrow$ show the TEM images of the $25 \% \mathrm{PO}_{4}{ }^{3-} / \mathrm{mSnO}_{2}$ after the third run, which showed no change in the morphology of the reused catalyst; also the FTIR of the pyridine adsorbed on the reused sample showed no significant loss in the acidity. The obtained results indicated that the catalyst had excellent reusability over three consecutive runs.

\section{Reaction mechanism}

The first step in the formation of hydroquinone diacetate is chemisorption of the carbonyl group of acetic anhydride on the Brönsted acid sites or Lewis acid sites of the catalyst, then on the adsorbed acetic anhydride on the Brönsted acid sites, Scheme 3A shows a nucleophilic attack by $\mathrm{OH}$ of hydroquinone to form an intermediate that breaks down to lose acetic acid in
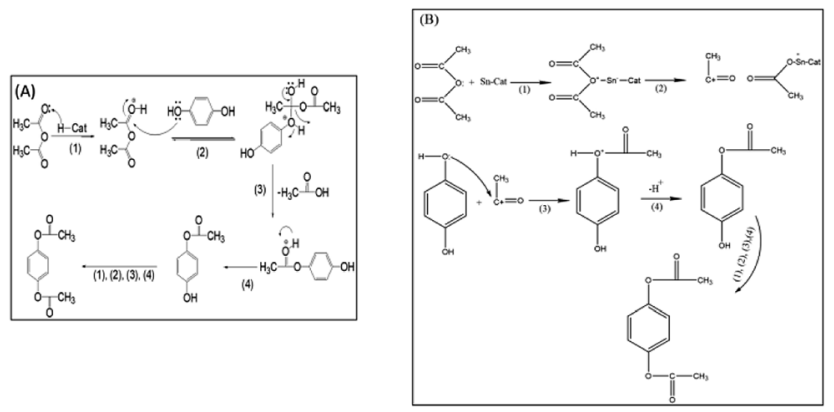

Scheme 3 Reaction mechanism for the formation of hydroquinone diacetate on: (A) Brönsted acid sites of a solid acid catalyst, (B) Lewis acid sites of a solid acid catalyst. the next step. Finally, the proton of the Brönsted acid site is eliminated to give hydroquinone acetate. The hydroquinone acetate reacts with another acetic anhydride - Brönsted acid site to give the final product. The mechanism of the formation of hydroquinone diacetate on Lewis acid sites starts by the chemisorption of the carbonyl group on the acetic anhydride, which breaks down to form acylium ion. Then the $\mathrm{OH}$ of hydroquinone attacks acylium ion to form an intermediate, which lose a proton to give hydroquinone acetate, which undergoes the same steps to give the product hydroquinone diacetate, Scheme 3B.

\section{Experimental}

\section{Synthesis of $\mathrm{PO}_{4}{ }^{3-} / \mathrm{mSnO}_{2}$}

For the synthesis of mesoporous tin oxide $\left(\mathrm{mSnO}_{2}\right), 15 \mathrm{ml}$ of $25 \mathrm{wt} \% \mathrm{NH}_{4} \mathrm{OH}$ solution was added to $100 \mathrm{ml}$ solution containing $2.0 \mathrm{~g}$ CTAB dropwise and stirred for $15 \mathrm{~min}$ until the

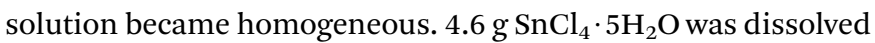
in $100 \mathrm{ml}$ of distilled water and then added to $\mathrm{NH}_{4} \mathrm{OH}$ CTAB solution slowly ${ }^{65,66}$ The $\mathrm{pH}$ was fixed at 8.5. The product was filtered and washed with $2 \mathrm{wt} \% \mathrm{CH}_{3} \mathrm{COONa}$ solution until excess surfactant, and $\mathrm{Cl}^{-}$ions were removed. The sample was then dried overnight at $800{ }^{\circ} \mathrm{C}$.

A series of $3,8,18,25,35$, and $45 \mathrm{wt} \% \mathrm{PO}_{4}{ }^{3-}$-supported $\mathrm{mSnO}_{2}$ samples were prepared by suspending $3.0 \mathrm{~g}$ of dried $\mathrm{mSnO}_{2}$ in $25 \mathrm{ml}$ of distilled water; then the calculated amount of $1 \mathrm{M} \mathrm{H}_{3} \mathrm{PO}_{4}$ solution was added dropwise to the suspension during stirring for $2 \mathrm{~h}$. Then the samples were calcined at $400{ }^{\circ} \mathrm{C}, 450{ }^{\circ} \mathrm{C}, 550^{\circ} \mathrm{C}$ and $650^{\circ} \mathrm{C}$ for 4 h. $3,8,18,25,35$ and 45 are denoted for the wt $\%$ of $\mathrm{PO}_{4}{ }^{3-}$.

\section{Characterization}

DTA and TGA of the uncalcined samples were carried out using a Shimadzu thermal analyzer, type $50-\mathrm{H}$. The measurements were carried out under $\mathrm{N}_{2}$ flow of $20 \mathrm{ml} \mathrm{min}^{-1}$ with a heating rate of $10^{\circ} \mathrm{C} \mathrm{min}^{-1}$. The XRD patterns were recorded using a PW 150 (Philips). The crystallite size (nm), unit cell $d_{110}$ and $a^{0}$ were calculated from the strongest peak 110 of $\mathrm{mSnO}_{2}$ at $2 \theta=26.54^{\circ}$ by Bragg's law. ${ }^{67}$

$$
\begin{gathered}
n \lambda=2 d \sin (\theta) \\
a^{\circ}=2 d / \sqrt{ } 3
\end{gathered}
$$

TEM images of the calcined $\mathrm{PO}_{4}{ }^{3-} / \mathrm{mSnO}_{2}$ samples were obtained using a Joel JEM-1230 operated at $120 \mathrm{KV}$. FTIR spectra of the calcined samples were recorded by using MATTSON 5000 FTIR spectrophotometer $\left(4 \mathrm{~cm}^{-1}\right.$ resolution and 16 scans) in dried $\mathrm{KBr}$ (Merck). Physically adsorbed nitrogen at $-196^{\circ} \mathrm{C}$ was used for elucidation of the texture properties of the calcined $\mathrm{P} /$ $\mathrm{mSnO}_{2}$ samples. The total acidity of the solid samples was measured by suspending $0.05 \mathrm{~g}$ of solid catalyst in $10 \mathrm{ml}$ of acetonitrile for $3 \mathrm{~h}$ and titrating with $0.1 \mathrm{~N} n$-butylamine base in acetonitrile. $^{35,57}$ An Orion 420 digital A pH-meter was used for measuring the potential variation. Lewis and Brönsted acid 
levels were determined from the exposure of the degassed solid samples at $200{ }^{\circ} \mathrm{C}$ to dried pyridine. ${ }^{68}$ After the removal of excess pyridine, a MATTSON 5000 FTIR spectrophotometer was used to record the spectra. For the $\mathrm{NH}_{3}$-TPD experiment, $200 \mathrm{mg}$ of the samples were kept under ammonia gas for $4 \mathrm{~h}$ at $100{ }^{\circ} \mathrm{C}$. Then the samples were flushed with helium, and then the temperature was raised from $50{ }^{\circ} \mathrm{C}$ to $700{ }^{\circ} \mathrm{C}$ at a ramping rate of $5{ }^{\circ} \mathrm{C} \min ^{-1}$ in the presence of helium, and the amount of $\mathrm{NH}_{3}$ desorbed was recorded using a TCD detector.

\section{Catalytic activity}

The synthesis of hydroquinone diacetate (1,4-diacetoxybenzene) was used to test the catalytic activity of the samples. $0.1 \mathrm{~g}$ of the activated catalyst at $120{ }^{\circ} \mathrm{C}$ was added to $3 \mathrm{ml}(0.032 \mathrm{~mol})$ of acetic anhydride and $1.1 \mathrm{~g}(0.01 \mathrm{~mol})$ of hydroquinone in a $50 \mathrm{ml}$ flask, and the mixture then stirred for $15 \mathrm{~min}$. After $15 \mathrm{~min}$, the clear solution was filtered to separate the catalyst, and the filtrate was poured into $500 \mathrm{ml}$ of crushed ice. The crystalline solids were dried to constant weight. The product was identified by FTIR, NMR spectroscopy and melting point determination. The \% yield of hydroquinone diacetate was then calculated.

\section{Conclusions}

Mesoporous $\mathrm{SnO}_{2}$ was successfully prepared through a simple method and loaded with different amounts of phosphate species. The XRD and TEM images showed that the samples were mesoporous. Phosphate species were homogeneously adsorbed on the surface of mesoporous $\mathrm{SnO}_{2}$ up to surface saturation coverage at $25 \mathrm{wt} \% \mathrm{PO}_{4}{ }^{3-}$ at which point the surface, area surface acidity level and acid strength were at a maximum. The acidity of the samples was found to decrease when the phosphate loading exceeded $25 \mathrm{wt} \%$, at which point polyphosphate multilayers were formed. Both Lewis and/or Brönsted acid sites were present on the catalyst surface. The synthesis of hydroquinone diacetate was used as a model reaction for testing the activity of the solid sample for the formation of bulky molecules. The maximum formation of hydroquinone diacetate and the surface acidities were found at $25 \mathrm{wt} \%$ phosphate loading and $400{ }^{\circ} \mathrm{C}$ calcination temperature, respectively. The catalyst could be successfully used many times without significant loss of its catalytic activity.

\section{Conflicts of interest}

There are no conflicts to declare.

\section{References}

1 A. I. Ahmed, S. A. El-Hakam, A. S. Khder and W. S. Abo ElYazeed, J. Mol. Catal. A: Chem., 2013, 366, 99-108.

2 E. Lotero, Y. Liu, D. E. Lopez, K. Suwannakarn, D. A. Bruce and J. G. Goodwin, Ind. Eng. Chem. Res., 2005, 44, 5353-5363.

3 A. Corma and H. García, Chem. Rev., 2003, 103, 4307-4366.
4 X. Zhang, K. Wilson and A. F. Lee, Chem. Rev., 2016, 116, 12328-12368.

5 M. A. Rezvani, A. F. Shojaie and M. H. Loghmani, Catal. Commun., 2012, 25, 36-40.

6 A. Bordoloi and S. B. Halligudi, J. Catal., 2008, 257, 283-290.

7 D. Hua, S.-L. Chen, G. Yuan, Y. Wang, Q. Zhao, X. Wang and B. Fu, Microporous Mesoporous Mater., 2011, 143, 320-325.

8 M. B. Smith and J. March, J. Med. Chem., 2007, 50, 22792280.

9 S. K. Samantaray and K. Parida, J. Mol. Catal. A: Chem., 2001, 176, 151-163.

10 S. K. Bharadwaj, S. Hussain, M. Kar and M. K. Chaudhuri, Appl. Catal., A, 2008, 343, 62-67.

11 S. K. Samantaray, T. Mishra and K. M. Parida, J. Mol. Catal. A: Chem., 2000, 156, 267-274.

12 S. K. Samantaray and K. Parida, Appl. Catal., A, 2001, 220, 920.

13 S. Furuta, H. Matsuhashi and K. Arata, Catal. Commun., 2004, 5, 721-723.

14 K. N. Rao, A. Sridhar, A. F. Lee, S. J. Tavener, N. A. Young and K. Wilson, Green Chem., 2006, 8, 790-797.

15 X. Chen, G. Clet, K. Thomas and M. Houalla, J. Catal., 2010, 273, 236-244.

16 G. Lu, X. Li, Z. Qu, Q. Zhao, H. Li, Y. Shen and G. Chen, Chem. Eng. J., 2010, 159, 242-246.

17 N. R. Shiju, M. AnilKumar, W. F. Hoelderich and D. R. Brown, J. Phys. Chem. C, 2009, 113, 7735-7742.

18 R. Kourieh, S. Bennici, M. Marzo, A. Gervasini and A. Auroux, Catal. Commun., 2012, 19, 119-126.

19 R. M. Martín-Aranda and J. Čejka, Top. Catal., 2010, 53, 141153.

20 N. Pal and A. Bhaumik, RSC Adv., 2015, 5, 24363-24391.

21 A. Taguchi and F. Schüth, Microporous Mesoporous Mater., 2005, 77, 1-45.

22 J. Fan, Y. Dai, Y. Li, N. Zheng, J. Guo, X. Yan and G. D. Stucky, J. Am. Chem. Soc., 2009, 131, 15568-15569.

23 Q. Yuan, A.-X. Yin, C. Luo, L.-D. Sun, Y.-W. Zhang, W.-T. Duan, H.-C. Liu and C.-H. Yan, J. Am. Chem. Soc., 2008, 130, 3465-3472.

24 L. Xu, H. Zhao, H. Song and L. Chou, Int. J. Hydrogen Energy, 2012, 37, 7497-7511.

25 Z. Miao, H. Zhao, H. Song and L. Chou, RSC Adv., 2014, 4, 22509-22519.

26 M. Srinivas, G. Raveendra, G. Parameswaram, P. S. Sai Prasad, S. Loridant and N. Lingaiah, J. Chem. Sci., 2015, 127, 897-908.

27 G. M. Maksimov, G. S. Litvak, A. A. Budneva, E. A. Paukshtis, A. N. Salanov and V. A. Likholobov, Kinet. Catal., 2006, 47, 564-571.

28 B. Mallesham, P. Sudarsanam, G. Raju and B. M. Reddy, Green Chem., 2013, 15, 478-489.

29 J. Zhu, B. Y. Tay and J. Ma, Mater. Lett., 2006, 60, 1003-1010. 30 M. Bhagwat, P. Shah and V. Ramaswamy, Mater. Lett., 2003, 57, 1604-1611.

31 Y. Leng, J. Liu, P. Jiang and J. Wang, Chem. Eng. J., 2014, 239, 1-7. 
32 J. I. Moreno, R. Jaimes, R. Gómez and M. E. Niño-Gómez, Catal. Today, 2011, 172, 34-40.

33 M. K. Lam and K. T. Lee, Fuel, 2010, 89, 3866-3870.

34 M. K. Lam, K. T. Lee and A. R. Mohamed, Appl. Catal., B, 2009, 93, 134-139.

35 Y. Wang, C. Ma, X. Sun and H. Li, Microporous Mesoporous Mater., 2001, 49, 171-178.

36 B. Tyagi, M. K. Mishra and R. V. Jasra, J. Mol. Catal. A: Chem., 2007, 276, 47-56.

37 R. Kim, H. S. Park, T. Yu, J. Yi and W.-S. Kim, Chem. Phys. Lett., 2013, 575, 71-75.

38 L. Körösi and I. Dékány, Colloids Surf., A, 2006, 280, 146-154.

39 S. Furuta, H. Matsuhashi and K. Arata, Appl. Catal., A, 2004, 269, 187-191.

40 M. Hayashi, T. Hyodo, Y. Shimizu and M. Egashira, Sens. Actuators, B, 2009, 141, 465-470.

41 X. Fan, T. Yu, Y. Wang, J. Zheng, L. Gao, Z. Li, J. Ye and Z. Zou, Appl. Surf. Sci., 2008, 254, 5191-5198.

42 W. Wang, Y. Pang and S. N. B. Hodgson, J. Sol-Gel Sci. Technol., 2010, 54, 19-28.

43 V. L. Struzhko, E. V. Senchilo and V. G. Il'in, Theor. Exp. Chem., 2006, 42, 53-59.

44 A. Martín, R. A. García, D. S. Karaman and J. M. Rosenholm, J. Mater. Sci., 2014, 49, 1437-1447.

45 R. A. García-Muñoz, V. Morales, M. Linares, P. E. González, R. Sanz and D. P. Serrano, J. Mater. Chem. B, 2014, 2, 79968004.

46 L. M. Fang, X. T. Zu, Z. J. Li, S. Zhu, C. M. Liu, L. M. Wang and F. Gao, J. Mater. Sci.: Mater. Electron., 2008, 19, 868-874.

47 S. Takenaka, R. Takahashi, S. Sato, T. Sodesawa, F. Matsumoto and S. Yoshida, Microporous Mesoporous Mater., 2003, 59, 123-131.

48 V. V. Fomichev and M. E. Poloznikova, Russ. Chem. Rev., 1994, 63, 399-409.

49 G. Ranga Rao, T. Rajkumar and B. Varghese, Solid State Sci., 2009, 11, 36-42.

50 F. M. Bautista, J. M. Campelo, A. García, D. Luna, J. M. Marinas, R. A. Quirós and A. A. Romero, Appl. Catal., A, 2003, 243, 93-107.

51 L. Korösi, S. Papp, V. Meynen, P. Cool, E. F. Vansant and I. Dékány, Colloids Surf., A, 2005, 268, 147-154.
52 G. Srinivasa Rao, N. Pethan Rajan, M. Hari Sekhar, S. Ammaji and K. V. R. Chary, J. Mol. Catal. A: Chem., 2014, 395, 486-493.

53 R. Gutiérrez-Báez, J. A. Toledo-Antonio, M. A. Cortes-Jácome, P. J. Sebastian and A. Vázquez, Langmuir, 2004, 20, 42654271.

54 S. Benadji, P. Eloy, A. Leonard, B. L. Su, C. Rabia and E. M. Gaigneaux, Microporous Mesoporous Mater., 2012, 154, 153-163.

55 A. I. Ahmed, S. A. El-Hakam, M. A. A. Elghany and W. S. A. ElYazeed, Appl. Catal., A, 2011, 407, 40-48.

56 E. Drzymała, G. Gruzeł, J. Depciuch, A. Budziak, A. Kowal and M. Parlinska-Wojtan, J. Phys. Chem. Solids, 2017, 107, 100-107.

57 D. O. Bennardi, G. P. Romanelli, J. C. Autino and L. R. Pizzio, Appl. Catal., A, 2007, 324, 62-68.

58 L. R. Pizzio, P. G. Vázquez, C. V. Cáceres and M. N. Blanco, Appl. Catal., A, 2003, 256, 125-139.

59 L. Marosi, G. Cox, A. Tenten and H. Hibst, J. Catal., 2000, 194, 140-145.

60 T.-H. Kim, M. Jang and J. K. Park, Microporous Mesoporous Mater., 2008, 108, 22-28.

61 J. W. Harris, M. J. Cordon, J. R. Di Iorio, J. C. Vega-Vila, F. H. Ribeiro and R. Gounder, J. Catal., 2016, 335, 141-154.

62 Y. Shimizu, T. Hyodo and M. Egashira, J. Eur. Ceram. Soc., 2004, 24, 1389-1398.

63 A. Yu and R. Frech, J. Power Sources, 2002, 104, 97-100.

64 C. Morterra, G. Cerrato, S. Ardizzone, C. L. Bianchi, M. Signoretto and F. Pinna, Phys. Chem. Chem. Phys., 2002, 4, 3136-3145.

65 W. Yu-de, M. Chun-lai, S. Xiao-dan and L. Heng-de, Nanotechnology, 2002, 13, 565.

66 A. S. Khder and A. I. Ahmed, Appl. Catal., A, 2009, 354, 153160.

67 P. Scherrer, Bestimmung der Größe und der inneren Struktur von Kolloidteilchen mittels Röntgenstrahlen, Nachrichten von der Gesellschaft der Wissenschaften zu Göttingen, Mathematisch-Physikalische Klasse, 1918, vol. 2, pp. 98-100. 68 A. S. Khder, E. A. El-Sharkawy, S. A. El-Hakam and A. I. Ahmed, Catal. Commun., 2008, 9, 769-777. 